\title{
Erratum to: Generation of an algorithm based on minimal gene sets to clinically subtype triple negative breast cancer patients
}

Brian Z. Ring ${ }^{1}$, David R. Hout ${ }^{2}$, Stephan W. Morris ${ }^{2}$, Kasey Lawrence ${ }^{2}$, Brock L. Schweitzer ${ }^{2}$, Daniel B. Bailey², Brian D. Lehmann ${ }^{3}$, Jennifer A. Pietenpol ${ }^{3}$ and Robert S. Seitz ${ }^{2^{*}}$

\section{Erratum}

Since publication of our article [1], we have noticed an error in labelling the p-value of one of the results. The original document read:

"The direction of association of BL1 with $\mathrm{pCR}$ or minimal residual cancer burden (RCB) in the 2188-gene model was similar $(\mathrm{OR}=1.91)$ but did not reach significance $(\mathrm{OR}=0.14)$."

This has been corrected to:

"The direction of association of BL1 with pCR or minimal residual cancer burden (RCB) in the 2188-gene model was similar $(\mathrm{OR}=1.91)$ but did not reach significance $(\mathrm{p}=0.14)$."

We regret the error.

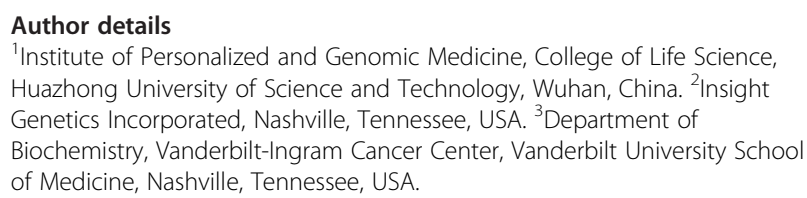

\section{References}

1. Ring BZ, Hout DR, Morris SW, Lawrence K, Schweitzer BL, Bailey DB, et al. Generation of an algorithm based on minimal gene sets to clinically subtype triple negative breast cancer patients. BMC Cancer. 2016;16:143. doi:10.1186/s12885-016-2198-0.

\footnotetext{
* Correspondence: rseitz@insightgenetics.com

${ }^{2}$ Insight Genetics Incorporated, Nashville, Tennessee, USA
}

Submit your next manuscript to BioMed Central and we will help you at every step:

- We accept pre-submission inquiries

- Our selector tool helps you to find the most relevant journal

- We provide round the clock customer support

- Convenient online submission

- Thorough peer review

- Inclusion in PubMed and all major indexing services

- Maximum visibility for your research

Submit your manuscript at

www.biomedcentral.com/submit

\section{() Biomed Central}

